\title{
PENINGKATAN KEUNGGULAN BERSAING SEBAGAI UPAYA PERLUASAN PANGSA PASAR DAN MENGHADAPI ERA 5.0
}

Lilis Sugi Rahayu Ningsih, M.Pd., Universitas Hasyim Asy’ari, lilissugi4@ gmail.com A.Fakhri Arifyanto,SP.,MM., Universitas Hasyim Asy’ari ahmadfakhriarifyanto@gmail.com Rohmad Prio Santoso,SE. M.M., Universitas Hasyim Asy’ari, rohmad.love@ gmail.com

\begin{abstract}
:
Changes without any predictions have resulted high enough pressure to make efforts in changing innovations that can resume sales activities in the UMKM Micro GO, especially in the UMKM Micro GO Community. The revival of the UMKM Micro GO Community in the Covid-19 Pandemic conditions requires strong synergy to be able to restore conditions. The role of this synergy is not only the government and UMKM actors, but also academics, financial institutions and policies that support the rise of UMKM. The introduction of efforts to utilize business through online/digitalization is a significant effort to restore the condition of the UMKM Micro GO Community which has experienced the negative impact of the pandemic. Competitive advantage in a pandemic condition requires the strength to know how a product has value proposition that can make the product superior, as well as an effort to expand market share and readiness to face the 5.0 era.
\end{abstract}

Keywords: UMKM Micro GO Community, Competitive advantage, Market share expansion

\begin{abstract}
Abstrak:]
Perubahan tanpa adanya prediksi sebelumnya mengakibatkan para pelaku UMKM khususnya pada Komunitas UMKM Mikro GO mengalami tekanan cukup tinggi untuk melakukan upaya perubahan inovasi yang dapat menjalakan kembali kegiatan penjualan. Kebangkitan Komunitas UMKM Mikro GO dalam kondisi Pandemi Covid 19 memerlukan sinergitas yang kuat untuk bisa mengembalikan kondisi . peran sinergi tersebut bukan hanya pemerintah dan pelaku UMKM, namun pihak akademisi, lembaga keuangan serta kebijakan yang mendukung kebangkitan UMKM sangat diperlukan. Pengenalan upaya pemanfaatan bisnis melalui online/ digitalisasi merupakan upaya cukup signifikan untuk mengembalikan kondisi Komunitas UMKM Mikro GO yang mengalami dampak negatif pandemi. Keunggulan bersaing dalam kondisi pandemi memerlukan kekuatan untuk mengetahui bagaimana produk memiliki value proposition yang dapat menjadikan keunggulan produk tersebut, serta sebagai upaya untuk perluasan pangsa pasar dan kesiapan menghadapi era 5.0
\end{abstract}

Keywords: Komunitas UMKM Mikro GO, Keunggulan bersaing, perluasan pangsa pasar

Copyright ( ) 2021, Dinamis: Jurnal Pengabdian Kepada Masyarakat https://ejournal.feunhasy.ac.id/dinamis 
Lilis Sugi Rahayu Ningsih, A.Fakhri Arifyanto, Rohmad Prio Santoso:

\section{PENDAHULUAN}

Bank Indonesia menyebutkan sebanyak 87,5 persen UMKM terdampak pandemi Covid-19, dari jumlah ini, sekitar 93,2 persen di antaranya terdampak negatif di sisi penjualan. Tingkat konsumsi menurun akibat penghasilan mengalami ketidakstabilan. Data lain dari Bank Indonesia menyebutkan \pm 64 juta pelaku UMKM, rentang $87 \%$ belum masuk ekosistem digital. Perubahan tanpa adanya prediksi sebelumnya mengakibatkan para pelaku UMKM khususnya pada Komunitas UMKM Mikro GO mengalami tekanan cukup tinggi untuk melakukan upaya perubahan inovasi yang dapat menjalakan kembali kegiatan penjualan. Kebangkitan Komunitas UMKM Mikro GO dalam kondisi Pandemi memerlukan sinergitas yang kuat untuk bisa mengembalikan kondisi . peran sinergi tersebut bukan hanya pemerintah dan pelaku UMKM, namun pihak akademisi, lembaga keuangan serta kebijakan yang mendukung kebangkitan UMKM sangat diperlukan.

Pengenalan upaya pemanfaatan bisnis melalui online/ digitalisasi merupakan upaya cukup signifikan untuk mengembalikan kondisi Komunitas UMKM Mikro GO yang mengalami dampak negatif pandemi. Keunggulan bersaing dalam kondisi pandemi memerlukan kekuatan untuk mengetahui bagaimana produk memiliki value proposition yang dapat menjadikan keunggulan produk tersebut. Terdapat dua kepentingan utama dalam value proposition yaitu keunggulan produk inti tersebut dan kegiatan tambahan untuk mendukung keunggulan produk tersebut. Produk inti mengutip penjelasan Bharadwaj et al.,( 1993,p83-84 ) menjelaskan bahwa keunggulan bersaing merupakan hasil dari implementasi strategi yang memanfaatkan berbagai sumberdaya yang dimiliki perusahaan. Dukungan dari keunggulan bersainga dapat di peroleh dari keunikan produk tersebut di bandingkan produk pesaing, harga yang menyesuaiakan tingkat pendapatan, jarang dijumpai dipasar karena keunikan yang dimiliki, tidak mudah ditiru pesaing karena kerahasiaan produk yang dihasilkan, tidak memiliki produk pengganti dari produk tersebut. Kepentingan kedua dalam keunggulan bersaiang adalah kegiatan tambahan untuk mendukung keunggulan produk tersebut yang dapat dilakukan dengan upaya memaksimalkan kegiatan penjualan melalui online atau digital. Kegiatan pemasaran online yang menarik, akses mudah, aman dan menyakinkan konsumen akan membuat konsumen merasa percaya terhadap kualitas dan layanan produk yang dijual.

Keunggulan bersaing dengan metode yang tepat akan meningkatkan perluasan pangsa pasar. Mengulas pernyataan Assauri (2000) pengertian pangsa pasar adalah suatu analisis untuk mempelajari besarnya bagian atau luasnya total pasar yang dapat dikuasai oleh perusahaan yang biasanya dinyatakan dalam prosentase yang disebut dengan istilah market share. Pengembangan produk dengan menggunakan pemasaran digital yang maksimal akat tepat sasaran pada segmen dan target.

Menghadapi era 5.0 pada para pelaku Komunitas UMKM Mikro GO selain melakukan keunggulan bersaing perlu menambahkan diversifikasi produk. Menurut Effendy (2001), diversifikasi produk didefinisikan sebagai suatu perluasan pemilihan barang dan jasa yang dijual oleh perusahaan dengan jalan menambah produk baru atau jasa ataupun memperbaiki tipe, warna, model, ukuran, jenis dari produk yang sudah ada dalam rangka memperoleh laba maksimal. Upaya melakukan diversifikasi produk melalui analisis kebutuhan kondisi pandemic yaitu, kebutuhan yang berkaitan dengan kesehatan, 
pelindung diri, makan minuman pengkuat imunitas tubuh, dan kegiatan yang dapat membantu mengelola stress akibat ketakutan dan over thinking.

\section{METODE KEGIATAN}

Pelaksanaan kegiatan dalam PKM melalui online zoom meeting. Metode tersebut dipilih berkaitan pandemic covid 19 yang mengharuskan untuk tetap menjaga kesehatan dan mengurangi kegiatan yang bersifat berkerumun. Kegiatan dilaksanakan pada tanggal 28 Maret - 11 April 2021 dengan para pelaku Komunitas UMKM Mikro GO berserta Bapak Ibu dosen manajemen Fakultas Ekonomi Universitas Hasyim Asy'ari. Kegiatan PKM dilakukan melalui tiga tahapan, yaitu pra kegiatan dengan melakukan analisis kebutuhan dan masalah yang dihadapai oleh objek. Kemudian tahap kedua adalah kegiatan inti atau proses PKM untuk mencarikan solusi dan pemecahan masalah. Tahap terakhir yaitu evaluasi untuk mengetahui tingkat pemahaman terhadap solusi yang diberikan.

\section{HASIL DAN PEMBAHASAN}

Para pelaku Komunitas UMKM Mikro GO memiliki beberapa kendala dalam memasarkan produk ketika kondisi pandemic covid 19, diantaranya jangkauan konsumen yang terbatas akibat himbauan tidak melakukan kegiatan berkerumun dan dirumah saja, sehingga para penjual harus melakukan sebuah inovasi untuk tetap melakukan kegiatan penjualan.

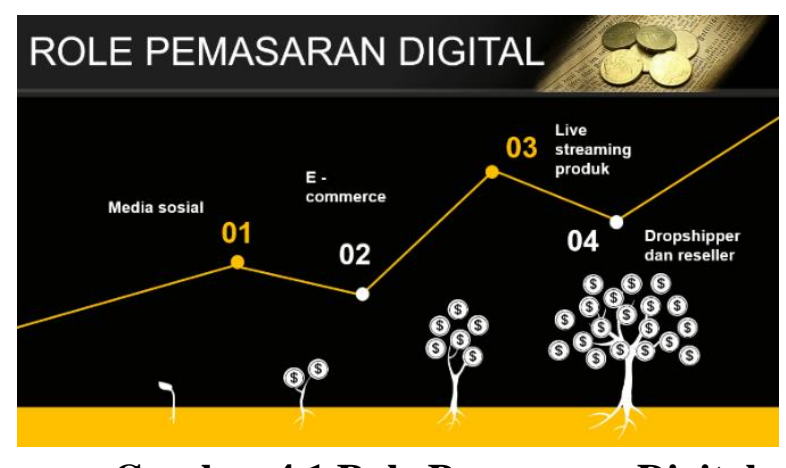

Gambar 4.1 Role Pemasaran Digital

Upaya yang dilakukan oleh pelaku UMKM adalah memasarkan melalui media social yang sudah dilakukan dengan menggunakan system grup maupun personal. Cukup efektif pengenalan produk melalui whatshapp, facebook, Instagram dan layanan COD, melihat perkembangan pemasaran digital yang pesat, para pelaku Komunitas UMKM Mikro Go perlu mencoba untuk memasarkan E-commerce melalui Shopee, Lazada, Tokopedia, maupun website resmi. 
Lilis Sugi Rahayu Ningsih, A.Fakhri Arifyanto, Rohmad Prio Santoso:

Peningkatan Keunggulan Bersaing Sebagai Upaya Perluasan Pangsa Pasar Dan Menghadapi Era 5.0
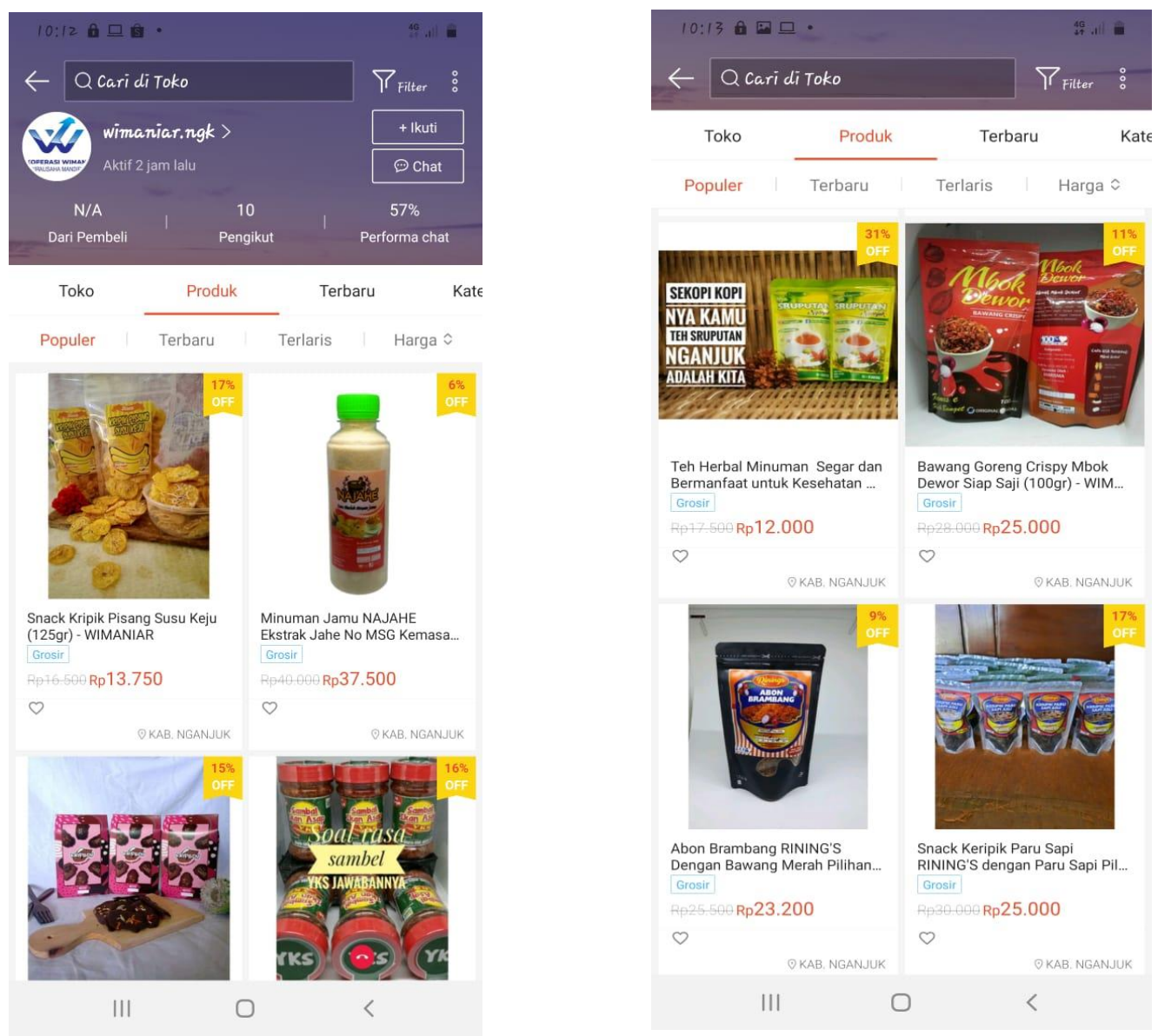

\section{Gambar 4.2 Produk Dipasarkan Melalui E-Commerce}

Keanekaragaman produk yang ditawarkan sangat menarik, keunikan produk, kejangkauan harga, inovasi produk yang tidak mudah ditiru, dan produk memiliki manfaat keamanan untuk di konsumsi. Nama - nama produk yang ada di Komunitas UMKM Mikro GO memiliki makna dan produksi yang aman serta pilihan bahan baku yang berkualitas. Produk produk unggulan di Komunitas UMKM Mikro GO merupakan hasil olahan dari sumber daya alam kabupaten Nganjuk. Produktivitas yang dihasilkan Komunitas UMKM Mikro GO mendapat dukungan dari berbagai pihak diantaranya kebijakan Pemerintah Daerah serta motivasi yang dimiliki oleh para pelaku Komunitas UMKM Mikro GO untuk meningkatkan pemasaran.

Pelaku Komunitas UMKM Mikro GO beranggotakan sekitar 250 anggota, semua adalah masyarakat Nganjuk yang memiliki kegiatan usaha produksi mandiri. Sekitar $80 \%$ dari hasil survei sementara pelaku menggunakan pemasaran langsung atau wouth of mouth. Sangat efektif jika dari orang yang langsung mengkonsumsi dan membangun kepercayaan, namun perluasan pasar akan mengalami kendala akibat pembelian yang dilakukan bersifat lokal. Dukungan pemasaran digital tidak hanya memperluas pangsa pasar, tetapi membantu mengupayakan pengenalan digitalisasi yang sudah berkembang.

Copyright (C 2021, Dinamis: Jurnal Pengabdian Kepada Masyarakat http://ejournal.feunhasy.ac.id/dinamis 


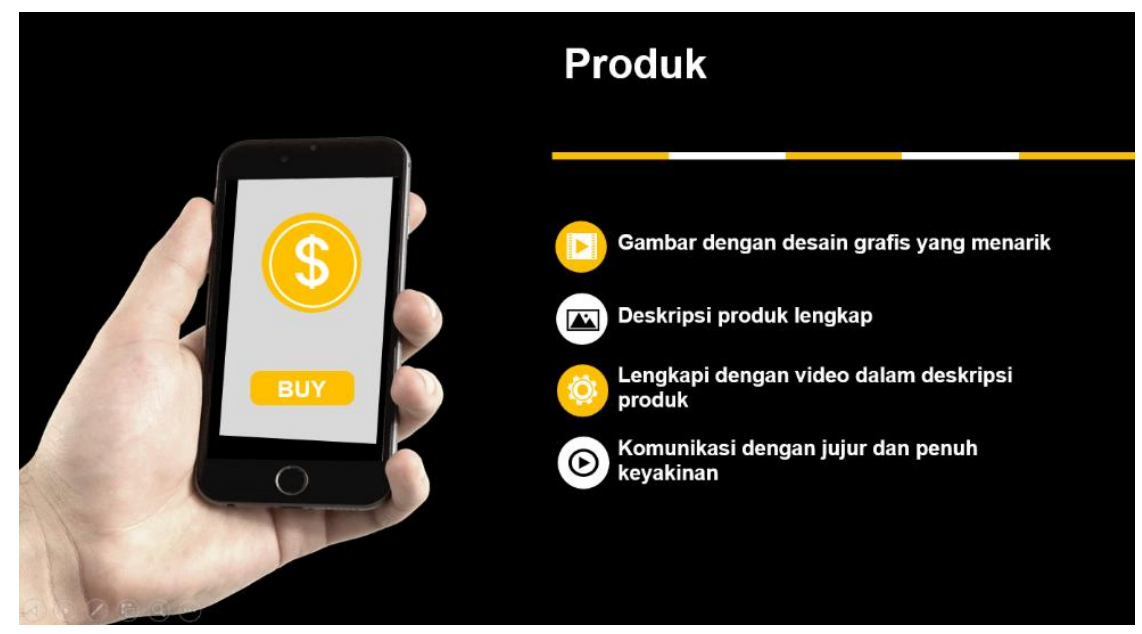

Gambar 4.2 Analisa Produk Dalam Pemasaran Digitalisasi

Peningkatan produktivitas pemasaran meski melalui digitalisasi harus menggunakan gambar dengan desain grafis yang menarik, yaitu menyesuaikan dengan segmen yang dituju. Pemasaran digital adalah pemasaran yang berbasis internet sehingga memudahkan pengusaha memasarkan suatu produk atau jasa, jika ingin memperkenalkan suatu produk atau jasa di internet produsen sebaiknya memperhatikan strategi pemasaran AIDA (awareness, interest, desire, action), (Johar et al., 2015: 5). Produk yang dipasarkan melalui digital menggunakan deskripsi yang jelas dan lengkap. Bukan hanya warna dan gambar yang menarik namun penjelasan produk dengan melengkapi menggunakan video akan menambah kepercayaan konsumen untuk memutuskan pembelian. Membangun komunikasi yang efektif penuh kesantunan dan kejujuran akan menambah keyakinan konsumen.

Kegiatan evaluasi PKM dengan para pelaku UMKM Mikro GO dengan memberikan bentuk kerjasama untuk melakukan pendampingan yang berkelanjutan dan berusaha untuk bekerjasama membangun kemudahan melakukan pemasaran digital dengan meningkatkan keunggulan bersaing melalui keunikkan produk, harga yang bersaing, produktivitas dalam daerah sebagai upaya untuk perluasan pangsa pasar dan menghadapi era 5.0 yang semakin cepat dan mudah dilakukan.

\section{KESIMPULAN}

Pemasaran digital melalui keunggulan bersaing sebagi upaya untuk memperluas pangsa pasar dan mempersiapkan para pelaku Komunitas UMKM Mikro GO menghadapi era 5.0 memerlukan pendampingan secara bertahap. Pengenalan dasar mengenai perkembangan pemasaran digital sangat membantu para pelaku Komunitas UMKM Mikro GO untuk paham serta melakukan inovasi kresi lebih awal. 
Lilis Sugi Rahayu Ningsih, A.Fakhri Arifyanto, Rohmad Prio Santoso:

Peningkatan Keunggulan Bersaing Sebagai Upaya Perluasan Pangsa Pasar Dan Menghadapi Era 5.0

\section{DAFTAR PUSTAKA}

Assauri, Sofian. (2000) Manajemen Pemasaran dasar Konsep dan Strategi. Jakarta: Rajawali Pers Cet 3

Bharadwaj, Sundar G, P.R.Varadarajan, \& Fahly, Jihn. (1993). "Sustainable Competitive Advantage in Service Industries: A Conceptual Model and Research Propositions “. Journal of Marketing. Vol.57,Oktober,p.83-99

Effendy, Rustam. (2001) Marketing Manajemen, Malang: Penerbit Institut Ekonomi dan Manajemen.

Johar., et al. (2015). Pengaruh Aida (Attention, Interest, Desire, Action) Terhadap Efektifitas Iklan Online (Survei pada Pembeli di Toko Online Adorable Project). JurnalAdministrasi Bisnis (JAB), Vol. 26 , No. 1. 